Arq. Bras. Med. Vet. Zootec., v.69, n.3, p.587-592, 2017

\title{
Fine needle aspiration cytology in feline skeletal muscle as a diagnostic tool for extramedullary plasmacytoma
}

\author{
[Citologia aspirativa por agulha fina no músculo esquelético felino como ferramenta diagnóstica para o \\ plasmocitoma extramedular] \\ D.B. Martins ${ }^{1}$, C.K. Rossato ${ }^{2}$, S.L. Silva ${ }^{3}$, S.S.N. Almeida ${ }^{4}$, L.S. Ribeiro ${ }^{3}$ \\ ${ }^{1}$ Universidade Federal de Goiás - Goiânia, GO \\ ${ }^{2}$ Universidade de Cruz Alta - Cruz Alta, RS \\ ${ }^{3}$ Aluna de graduação - Universidade Federal de Goiás - Goiânia, GO \\ ${ }^{4}$ Aluna de Residência - Universidade Federal de Goiás - Goiânia, GO
}

\begin{abstract}
Extramedullary noncutaneous plasmacytoma (ENP) is a myeloproliferative disorder of plasma cells that rarely affects cats. This paper describes an ENP case revealed by fine needle aspiration cytology (FNAC) of the mass in the skeletal muscle of an 8-month-old, male, mixed breed cat, which had a nodule in the left hind limb. The rapid immunoassay test confirmed the presence of feline leukemia virus (FeLV). The animal necropsy macroscopically showed the nodule came from the semimembranosus muscle. Histopathological examination ratified the cytological findings. Thus, this paper alerts to the existence of plasmacytoma located in the skeletal muscle of feline species. FNAC is a quick and efficient method for diagnosis of ENP.
\end{abstract}

Keywords: cat, aspiration biopsy, feline leukemia virus, skeletal muscle

\section{RESUMO}

O plasmocitoma extramedular (PEM) não cutâneo é um distúrbio mieloproliferativo de plasmócitos que raramente acomete felinos. Este trabalho descreve um caso de PEM no músculo esquelético de um gato, macho, sem raça definida, de oito meses de idade, que apresentava um aumento de volume no membro pélvico esquerdo. A citologia aspirativa por agulha fina (CAAF) da massa revelou tratar-se de PEM. O teste imunoenzimático rápido confirmou a presença do vírus da leucemia felina (FeLV). Na necropsia do animal, macroscopicamente, percebeu-se que o nódulo era originário do músculo semimembranoso. $O$ exame histopatológico ratificou os achados citológicos. Desta forma, alerta-se para a existência de plasmocitoma com localização em músculo esquelético na espécie felina, sendo a CAAF um método alternativo rápido e eficaz para o seu diagnóstico.

Palavras-chave: gato, biópsia aspirativa, músculo esquelético, vírus da leucemia felina

\section{INTRODUCTION}

Fine needle aspiration cytology (FNAC), also known as aspiration biopsy, represents one of the most used forms of biopsy nowadays (Rosolem et al., 2013). It provides significant benefits for patients due to the minimal invasion, fast performance, and low cost (Sharkey et al., 2014). This diagnostic tool, when combined with the

Recebido em 19 de maio de 2016

Aceito em 20 de junho de 2016

E-mail: vetdanielimartins@yahoo.com.br histopathologic analysis, significantly expands the definitive diagnosis (Rosolem et al., 2013).

The plasma cell neoplasms are classified as multiple myelomas, solitary plasmacytoma, and extramedullary plasmacytoma (Majzoub et al. 2003; Radhakrishnan et al., 2004; Mellor et al., 2007). This kind of neoplasm is considered rare in cats (Majzoub et al., 2003). The extramedullary noncutaneous form of plasmacytoma (ENP) has its origins in soft tissue 
and is characterized by its location outside the bone marrow (Radin and Wellman, 2004; Adelman et al., 2014).

The presence of plasmacytoma hardly occurs in the muscular system, and the diagnosis is usually made when it has already spread to other organs, as reported in human (Köse et al., 2015) and feline cases (Ward et al., 1997). Besides, the muscle changes are poorly investigated by the FNAC technique (Sharkey et al., 2014).

However, literature often reports plasmacytoma cases with a primary diagnosis made by histopathology (Majzoub et al., 2003; Mellor et al., 2007; Adelman et al., 2014). There are few reports of plasmacytoma in which the diagnosis was made by FNAC with subsequent ratification by histopathology (Mellor et al., 2007; Igase et al., 2015). This report aims to describe the case of an 8-month-old, FeLV-positive, feline diagnosed by FNAC, with extramedullary plasmacytoma in the semimembranosus muscle, making this case unusual.

\section{CASUISTRY}

A non-castrated male cat, mixed breed, 8-monthold, weighing $2.5 \mathrm{~kg}$ received care at the Veterinary Hospital. The animal presented difficulties to walk for the last two months and could not stay in physiological position to urinate and defecate. He was also showing appetite loss and hypodipsia.

At the clinical examination, all physiological parameters were normal. During the palpation, the left pelvic limb (LPL) was atrophied when compared to the contralateral member. LPL showed a mass of soft consistency of about $2 \mathrm{~cm}$. The patient presented pain at the site during palpation (Figure 1A).

The requested $\mathrm{CBC}$ revealed mild normochromic macrocytic anemia. Biochemical examination showed a slight decrease of urea. Radiographic image of the LPL excluded bone involvement.

In addition to these findings, FNAC was made and demonstrated the presence of round cells compatible with plasma cells, with anisocytosis, cytoplasmic basophilia, and vacuolation, eventual binucleation/multinucleation, rare mitosis, rare micronuclei, coarse chromatin, single or multiple prominent nucleoli, and some nucleoli in an angular form. Moreover, there was rare intermingled amyloid material in the cells. Cytological characteristics of the patient's sample indicated plasmacytoma (Figure 1B).

Thus, we chose to make the rapid enzyme immunoassay for the feline immunodeficiency virus (FIV) and feline leukemia virus (FeLV) (Snap Test FIV / FeLV Combo, Idexx $\left.{ }^{\circledR}\right)$ ). The result was positive for FeLV.

During hospitalization of the patient, chemotherapy and surgical protocol were suggested. The tutor refused such procedures for financial reasons. After four days in the hospital, the patient did not show improvement, and the owner opted for euthanasia due to the life quality expectation of the animal. The cat was referred to necropsy after authorization by the proprietor.

At necropsy, we observed macroscopically a muscle atrophy and presence of a well-defined mass with about $2 \mathrm{~cm}$ that had infiltrated the semimembranosus muscle (Figure 1C). The cut surface was white, soft and circumscribed. At the microscopic analysis, we verified plasma cell proliferation arranged in cords supported by thin septa of connective tissue.

These round cells varied in size, with abundant eosinophilic cytoplasm and hyperchromic nucleus with one or more eccentrically located nucleoli. Sometimes the presence of binucleated cells and mitotic figures could be observed, confirming the findings of the FNAC, that is, extramedullary plasmacytoma (Figure 1D). 


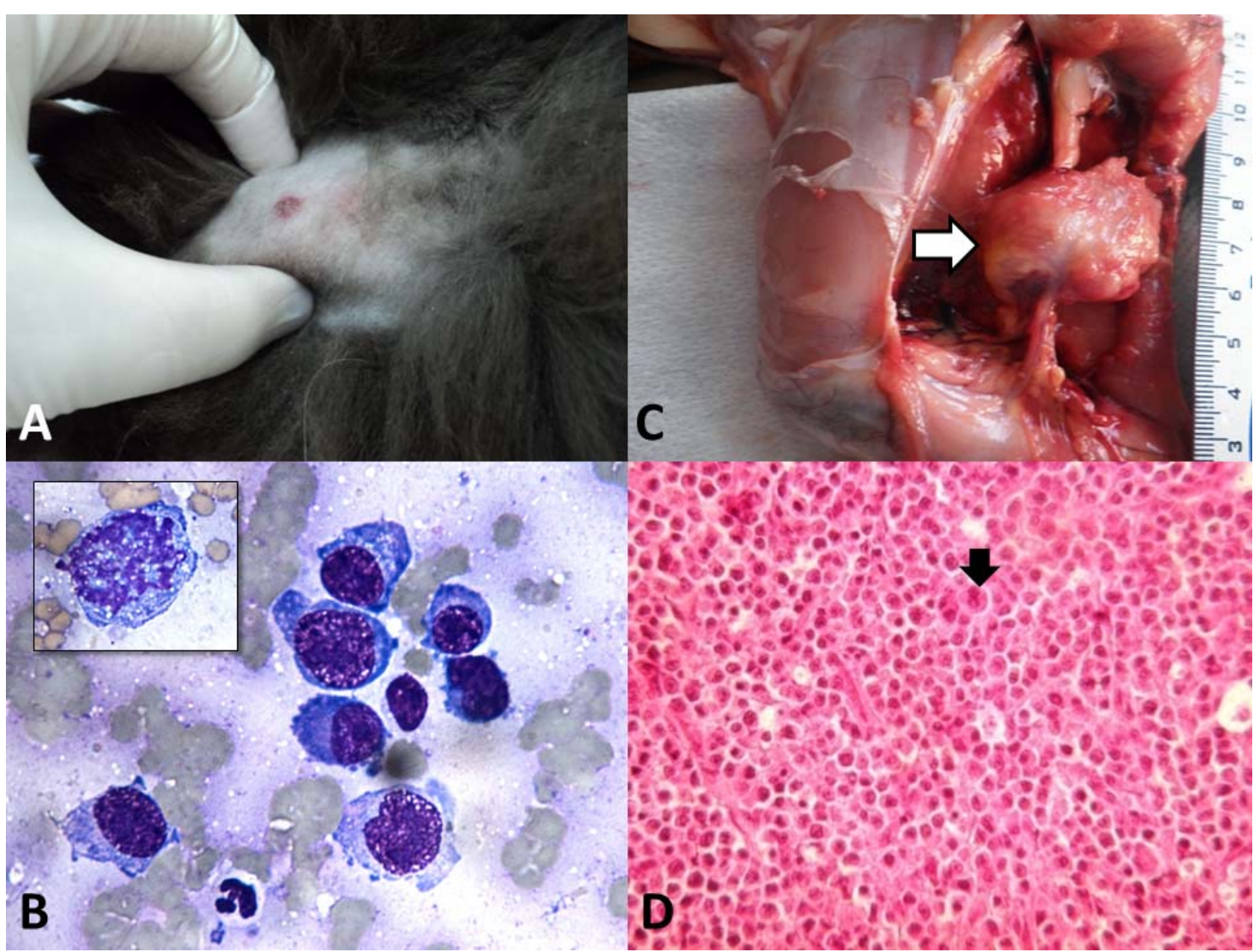

Figure 1. Extramedullary noncutaneous plasmacytoma in the skeletal muscle of a feline. A) Noticeable nodule during palpation. B) Cytological sample with neoplastic plasma cells evidencing malignancy features such as anisocytosis, cytoplasmic basophilia, anisocariosis, coarse chromatin, single or multiple prominent nucleoli, with an angled form and in some cells. In particular, an aberrant mitotic figure is observed. Diff-Quick, 100x. C) Macroscopic examination of the semimembranosus muscle with the presence of a circumscribed mass of about $2 \mathrm{~cm}$. D) Histological section of the neoplastic mass with the presence of plasma cells arranged in cords, supported by discrete fibrous septa. These cells contain eosinophilic cytoplasm and hypercromic nucleus with eccentric location. Presence of binucleate cells (arrow). HE, 40x. 254x190mm (96 x 96 DPI)

\section{DISCUSSION}

Plasmacytoma has a low frequency in cats, and information on clinical cytology in veterinary medicine is less extensive than that available in human medicine, with less regulation of cytological evaluation approach and reports of results (Sharkey et al., 2014). Thus, this report emphasizes significant aspects of the cytological diagnosis of ENP in a young feline's skeletal muscle.

The average age of the onset of the disease in cats is 8.2 years, varying from $6-20$ year-old. The cutaneous/subcutaneous location is more common in feline plasmacytoma (MAJZOUB et al., 2003), and the involvement of the muscular system is rare in the disease, even when the disease spreads to other sites (Ward et al., 1997).

Our patient was taken to the veterinary hospital for presenting difficulty in progressive locomotion, which affected its physiological position to urinate and defecate. This difficulty was linked to severe pain on LPL. Only through palpation we noticed the presence of a soft consistency nodule. There has been a report about an animal presenting hind limb ataxia, decreased tail movements, and muscular weakness, as well as a painless mass in the sacral dorsal region (Mellor et al., 2007). As the cat in the study mentioned had free access to the street 
and was predisposed to fights for being a noncastrated male young cat, there was an initial suspicion of muscle trauma. The history of trauma has already been included in plasmacytoma suspicion in cats (Michau et al., 2003). As there was no history of vaccines or injections in our patient, the possibility of a postvaccination sarcoma was discarded.

Complementary tests were necessary to find the correct diagnosis for the patient. Sometimes the laboratory tests, such as $\mathrm{CBC}$ and serum chemistries, do not reveal changes resulting from plasmacytoma, except for the increased value of proteins (Mellor et al., 2007). The radiographic examination can help in cases where there is bone involvement. In our case, this examination allowed the exclusion of bone involvement and demonstrated radiopacity alteration in the soft tissue region. We observed the beginning of an anemic process, which would not necessarily be linked to the neoplastic process since mild signs of regeneration were seen, such as anisocytosis and Howell-Jolly bodies. Although the total proteins were within the reference values, urea below the reference values for the species can be explained by the appetite loss of the feline.

Immunohistochemical study for FeLV using p27 protein in nine cats with plasmacytoma showed no viral involvement (Majzoub et al., 2003). Two isolated case reports, one using serology (Michau et al., 2003) and another by rapid enzyme immunoassay (Igase et al., 2015), showed negative results for feline immunodeficiency virus (FIV) and FeLV. However, a cat was diagnosed concurrently with plasmacytoma and as positive for FIV (Ward et al., 1997).

Several pieces of evidence do not seem to correlate the appearance of plasmacytoma to infection by retroviruses. However, it is worth mentioning the significant number of papers that did not describe the investigation of these viruses in their cases (Radhakrishnan et al., 2004; Mellor et al., 2007; Mellor et al., 2008). Thus, it is possible that the presence of FeLV in the present report is not directly involved in the development of the neoplasm, although further studies with this focus are necessary. The age of our patient (only 8-month-old) is also relevant. FeLV mainly affects young cats and can induce different tumors of hematopoietic origin due to its replication features (Hartmann, 2012).

The cytological examination can be used for the diagnosis of the primary mass of ENP (Igase et al., 2015) or even metastasis, such as sentinel lymph nodes (Radhakrishnan et al., 2004). The round cell tumors, a group in which the plasmacytoma is inserted, usually have connection with hematopoietic cells, being, in this case, the plasma cells. Cytologically, this group presents samples that exfoliate a good number of individual cells for analysis, and feature rounded nuclei and defined cytoplasmic borders (Raskin, 2011).

The cytological characteristics described in the feline sample refer to a combination of malignancy criteria. In FNAC, the neoplastic plasma cells showed moderate anisocytosis, cytoplasmic basophilia, round to ovoid nuclei with an unusual location, coarse nuclear chromatin, and inconspicuous nucleoli. There are mild anisocariosis and the nucleus:cytoplasm degree is variable. A clear perinuclear halo was also observed in many cells corresponding to the region of the Golgi complex (Mellor et al., 2007), besides multinucleate or binucleate cells (Radin and Wellman 2004).

Mitotic figures were rarely seen in plasmacytoma (Rannou et al., 2009), and the presence of amyloid matrix was noted in few cases (Radhakrishnan et al., 2004). We found in the patient's sample many of cytological characteristics described for plasmacytoma, even those considered rare, such as mitotic figures, or unusual, as the amyloid matrix. Multinucleated cells with an odd number of nuclei, as well as the presence of micronuclei were significant, which could be related to a more severe malignancy.

Moreover, prominent nucleoli observed in this case were single or multiple with an angular shape in some cells, which also refers to malignancy. However, stained cytological smears with fast colorations, such as Diff-Quick that was used in the present case, should be analyzed with caution, since it can evidence the nucleoli (Meinkoth et al., 2009).

A cytological sampling of some plasmacytomas may have intensively anaplastic cells, which do not remember the original morphology of plasma 
cells (Radin and Wellman, 2004). Thus, it is noteworthy that despite the simplicity and efficiency of FNAC, the use of histopathological examination may still be necessary. If both methods are combined, they will allow more informed interpretations, increasing the diagnostic accuracy (Rosolem et al., 2013).

In the histopathological examination, our findings agree with the literature, where plasmacytomas are seen as a well-defined proliferation of round cells which comprised in strands, trabeculae or nests (Goldschmidt et al., 2002; Gross et al., 1992; Yager and Wilcock, 1994), poorly defined and separated by small amount of connective tissue (Gross et al., 1992; Yager and Wilcock, 1994). These plasma cells range from small cells with round nuclei with an odd location to large cells showing a moderate amount of amphophilic or eosinophilic cytoplasm with round to oval nuclei (Goldschmidt and Hendrick, 2002; Gross et al., 1992). Multinucleate or binucleate cells can often be found in extramedullary plasmacytomas (Goldschmidt and Hendrick, 2002; Gross et al., 1992; Yager and Wilcock, 1994), giving a very pleomorphic appearance to the tumor (Yager and Wilcock, 1994). Although the histologic features of plasmacytomas denote almost always a severe malignancy, the biological behavior of this tumor is usually benign (Gross et al., 1992).

However, ENP with unusual sites location, such as bone and gastrointestinal tract, tend to be more aggressive than those found in traditional points like the skin (Radin and Wellman, 2004; Radhakrishnan et al., 2004). Thus, our patient's FNAC proved to be an easy technique to perform. It was inexpensive, efficient, and especially was able to provide a rapid diagnosis of feline muscle plasmacytoma.

\section{CONCLUSIONS}

Skeletal muscle may be a primary site of ENP in feline species. Although the most frequent diagnosis for plasmacytoma is histopathology, FNAC is becoming more popular due to its lower cost, effectiveness in diagnosis and ease in performing the technique as noted in this report case. There is a lack of studies involving young feline patients infected with retroviruses such as FeLV, and the incidence of this kind of tumor.

\section{BIOETHICS AND BIOSECURITY COMMITTEE APPROVAL}

This report was carried out in the routine of the Veterinary Hospital of Cruz Alta and was not part of any project, consisting only in a case report.

\section{REFERENCES}

ADELMAN, L.; LARSON, V.; SISSENER, T. et al. Extramedullary plasmacytoma in the lung of a doberman pinscher dog . Can. Vet. J., v.55 p.1237-1240, 2014

GOLDSCHMIDT, M.H.; HENDRICK, M.J. Tumors of the skin and soft tissues. In: MEUTEN, D.J. Tumors in domestic animals. 4.ed. Ames: Iowa State, 2002. p.44-117.

GROSS, T.L.; IHRKE, P.J.; WALDER, E.J. Veterinary dermatopathology: a macroscopic and microscopic evaluation of canine and feline skin disease. St. Louis: Mosby, 1992. 520p.

HARTMANN, K. Clinical aspects of feline retroviruses: a review. Viruses, v.4, p.2684-2710, 2012.

IGASE, M.; MIYAMA SHIMOKAWA, T.; KAMBAYASHI, S. et al. Bimodal immunoglobulin A gammopathy in a cat with feline myeloma-related disorders. J. Vet. Med. Sci., v.78, p.691-695, 2015.

KÖSE, M.; BURANIQI, E.; AKPINAR, T.S. et al. Relapse of multiple myeloma presenting as extramedullary plasmacytomas in multiple organs. Case Rep. Hematol., v.2015, p.1-6, 2015.

MAJZOUB, M.; BREUER, W.; PLATZ, S.J. et al. Histopathologic and immunophenotypic characterization of extramedullary plasmacytomas in nine cats. Vet. Pathol., v.40, p.249-253, 2003.

MEINKOTH, J.H.; COWELL, R.L.; TYLER, R.D. Tipos celulares e critérios de malignidade. In: COWELL, R.L.; TYLER, R.D. ; MEINKOTH, J.H. et al. Diagnóstico citológico e hematologia de cães e gatos. 3ed. São Paulo: MedVet, 2009. cap.2. p.20-46. 
MELLOR, P.J.; HAUGLAND, S.; SMITH, K.C. et al. Histopathologic, immunohistochemical, and cytologic analysis of feline myeloma-related disorders: further evidence for primary extramedullary development in the cat. Vet. Pathol., v.45, p.159-173, 2008.

MELLOR, P.J.; POLTON, G.A.; BREARLEY, M. et al. Solitary plasmacytoma of bone in two successfully treated cats. J. Feline Med. Surg., v.9, p.72-77, 2007.

MICHAU, T.M.; PROULX, D.R.; RUSHTON, S.D. et al. Intraocular extramedullary plasmacytoma in a cat. Vet. Ophthalmol., v.6, p.177-181, 2003.

RADHAKRISHNAN, A.; RISBON, R.E.; PATEL, T.R. et al. Progression of a solitary, malignant cutaneous plasma-cell tumour to multiple myeloma in a cat. Vet. Comp. Oncol., v.2, p.36-42, 2004.

RADIN, M.J.; WELLMAN, M.L. Nestlé purina: interpretation of canine and feline cytology. Delaware: Gloyd Group, 2004, 92p.

RANNOU, B.; HÉLIE, P.; BÉDARD, C. Rectal plasmacytoma with intracellular hemosiderin in a dog. Vet. Pathol., v.46, p.1181-1184, 2009.
RASKIN, R.E. Categorias gerais de interpretação citológica. In: RASKIN, R.E.; MEYER, D.J. Citologia clínica de cães e gatos: atlas colorido e guia de interpretação. 2.ed. Rio de Janeiro: Elsevier, 2011. cap.2. p.15-25.

ROSOLEM, M.C., MOROZ, L.R., RODIGHERI, S.M. et al. Estudo retrospectivo de exames citológicos realizados em um Hospital Veterinário Escola em um período de cinco anos. Arq. Bras. Med. Vet. Zootec., v.65, p.735-741, 2013.

SHARKEY, L.C.; SEELIG, D.M.; OVERMANN, J. All lesions great and small, part 1: diagnostic cytology in veterinary medicine. Diagnost. Cytopathol., v.42, p.535543, 2014.

WARD, D.A.; MCENTEE, M.F.; WEDDLE, D.L. Orbital plasmacytoma in a cat. J. Small Anim. Pract., v.38, p.576-578, 1997.

YAGER, J.A.; WILCOCK, B.P. Color atlas and text of surgical pathology of the dog and cat: dermatopathology and skin tumors. London: Wolfe, 1994. p.239-313. 